GENDER STUDIES 20(1)/2021

\title{
sciendo
}

\subsection{8/genst-2022-0007}

\section{“ARE YOU A BAD BOY?": VARIATIONS OF THE AMERICAN ADAM IN DAVID LYNCH'S BLUE VELVET}

\author{
SOFÍA MARTINICORENA \\ Universidad Complutense de Madrid \\ smartini@ucm.es
}

\begin{abstract}
This paper mobilises R. W. B. Lewis' myth of the American Adam, articulated in 1955, to examine David Lynch's 1986 film Blue Velvet's formulaic use of this masculinity archetype. Lewis' ideal type of innocent masculinity is replicated by Blue Velvet's protagonist, Jeffrey Beaumont (Kyle MacLachlan), who must navigate the stereotyped conventions of good and evil against the backdrop of the idealised US suburb. Beyond the generalised assessment of David Lynch as the quintessential eccentric, this article brings to the fore the ways in which his work can be analysed as formulaic, paying special attention to the interaction between masculinity, spatiality, and dominant national mythology.
\end{abstract}

Keywords: David Lynch, American Adam, masculinity, myth, suburbs, R. W. B. Lewis.

Lynch's work resides in the complicated zone where the beautiful and the damned collide.

Kristin McKenna

\section{Introduction: An American Adam in the suburbs}

This book has to do with the beginnings and the first tentative outlines of a native American mythology. The period I cover runs from about 1820 to 1860; the scene, for the most part, is New England and the Atlantic seaboard. The cast of characters is large, and would be a great deal larger if every person were included who, by act or utterance, contributed to the formation of the American myth (Lewis, 2001, p. 1)

Thus begins The American Adam: Innocence, Tragedy, and Tradition in the Nineteenth Century. The first lines of the volume provide the frame for a narrative constructed with the 


\section{GENDER STUDIES 20(1)/2021}

purpose of creating a purely American original mythology. ${ }^{1}$ This book was published by Myth and Symbol school scholar R. W. B. Lewis in 1955, meeting instant success ${ }^{2}$ as a landmark of American literary criticism. In it, he defined this allegedly quintessential American archetype as

the hero of the new adventure: an individual emancipated from history, happily bereft of ancestry, untouched and undefiled by the usual inheritances of family and race; an individual standing alone, selfreliant and self-propelling, ready to confront whatever awaited him with the aid of his own unique and inherent resources $(2001$, p. 5)

Lewis' proposal ushered in yet another re-elaboration of the enduring cult of individualism so rife in US culture. Whilst the archetype presented in this description had a long-standing tradition in US literature, with writers such as Ralph Waldo Emerson embodying the conceptual pillars of the self-reliant American, it was Lewis who gave it the systematic relevance of a critical tool by arguing for its pervasiveness in nineteenth-century writing (Lewis, 2001, p. 3). Despite Lewis' vindication of such ubiquity, he also conveyed, in the epilogue to the book, a profound scepticism about the possibility of an American Adam in his contemporary times. Scepticism notwithstanding, the reality is that the idea of an American Adam prevailed in scholarly discussion due to the interpretive possibilities it offered for cultural analysis. ${ }^{3}$

From its publication onwards, this archetype has been meant to represent "the American experience" in ways that frequently fall into more or less overt forms of American exceptionalism ${ }^{4}$ but that nonetheless have established it as "a fundamental organizing narrative of American identity in the twentieth century" (Mitchell, 2011, p. 1) and even, as some critics claim, "the ruling metaphor of American culture" (Patea, 2001, p. 18). The truth is that taking the individual experiences of a self-reliant white male as the epitome of the so-called American experience is evidently problematic, and so Lewis' classic argument is rightfully considered

\footnotetext{
${ }^{1}$ National mythology here is understood, as per Richard Slotkin, as a "national phenomenon of mythconsciousness" based on a "continual preoccupation with the necessity of defining or creating a national identity" (1996, p. 4). The American Adam, then, can be understood as an expression of said preoccupation in that it is an archetype that, according to Lewis, captures what he terms "a native American mythology" (2001, p. 1)

${ }^{2}$ See Viorica Patea (2001, pp. 22-24) for an overview of texts deeply influenced by Lewis' volume and for additional commentary on works that revise it.

${ }^{3}$ These possibilities have trespassed the boundaries of literary and cultural analysis. See Terence Ball (2002, pp. 273-296) for an exploration of the American Adam myth's presence in unlikely fields such as political philosophy or physics.

${ }^{4}$ The deep link of the Myth and Symbol school of Americanists with American exceptionalism is beyond the scope of this paper, but an eloquent exploration of the biases and shortcomings of this school of criticism can be found in Nina Baym's now classic indictment "Melodramas of Beset Manhood: How Theories of American Fiction Exclude Women Authors" (1981).
} 
outdated in today's scholarly discussion. However old-fashioned the Adamic archetype may be in terms of academic analysis, not few cultural products in the twentieth century dealt, more or less explicitly, with characters and situations that revolved around the topic of the loss of innocence so commonly associated to canonised American authors, not only to those Lewis is focusing on, i.e. nineteenth-century New Englanders, but also twentieth-century classics like J.D. Salinger's The Catcher in the Rye, Ralph Ellison's Invisible Man or Saul Bellow's The Adventures of Augie March, to name a few that Lewis himself mentions in his epilogue (2001, p. 198). With the exception of Ellison's Invisible Man in the examples above, the different incarnations of Adam offered by Lewis tend to construct a masculinity type that is consistently embodied by a white, male, heterosexual man. Typically, too, the American Adam is young rather than old, which emphasises the innocent quality that defines him. In this respect, Lynda Boose explains how the US "has always valorized male adolescence" given its penchant for a "heroized mythology of baby-faced gunfighters like Billy the Kid" as well as for a "traditional representation of its national historical self as the 'young,' 'new,' and 'innocent' nation" (1993, p. 604).

Additionally, the masculinity type evoked by this archetype is that of a disembodied, "essentialized American identity" (Mitchell, 2011, p. 10) that considers "the marriage of both gender and national identity as an essential aspect of the self" (Mitchell, 2011, p. 7). Jonathan Mitchell, who has reassessed the cultural impact of Lewis' proposal in his study Revisions of the American Adam: Innocence, Identity, and Masculinity in Twentieth-Century America, claims that the American Adam in fact conveys "an ideology of masculinity" (2011, p. 7) that corresponds to "the American identity" (2011, p. 6). Indeed, the Adamic archetype emblematises the aspirational masculine qualities that have driven the dominant national selfimage of the United States: innocence, self-reliance, and individualism. These qualities have frequently been channelled through masculine figures that have ended up becoming enduring icons in popular culture, like the rugged pioneer, the cowboy, or the soldier, and that have come to represent the aspirational national identity. Mitchell summarises this correspondence asserting that, according to the Adamic archetype, "being Masculine and being American become the same thing" (2011, p. 25, emphasis in original). The American Adam, then, should be understood as one iteration among many to establish a paradigm for an ideal national subject, the protagonist of a national mythology — a paradigm that emblematises the so-called national experience in the figure of a young, innocent man, identified as hero.

The emergence of national masculinity archetypes tends to be associated with certain spaces where their archetypal qualities may be realised. If the pioneer's ideal setting was the 


\section{GENDER STUDIES 20(1)/2021}

mythic frontier, the American Adam becomes fully realised in the suburban setting. Suburban developments in the United States became ubiquitous in the post-war years, when suburban housing became a mass-produced commodity available to the middle classes. It is not by chance that an archetype defined as "internal and essentialized innocence" (Mitchell, 2011, p. 6) was conceived, or refashioned, in the years following World War II. The American Adam myth holds an affinity with a time when, after the horrors of the war, citizens sought the peace and safety that they had been lacking. As Carmen Méndez has argued, the post-war years in the United States were defined by a desire for a restored order of traditional families and communal stability, after the turmoil that citizens had experienced during the combat (2014, p. 117). This urge for protection crystallised in a celebration of the suburbs as the space that ensured the values of domesticity and alleged safety. The suburbs were consequently construed as Eden regained, "the promised land of the American middle class" (Beuka, 2004, p. 5) based on "willed communal innocence" (2004, p. 9). Added to the post-war desire for comfort was the ideological framework imposed by the Cold War, which also instigated the proliferation of cultural narratives that boosted the country's national self-image. Within this context, "Lewis understood the mythic force of classic American Literature and was himself constructing myths of innocence for post-war America and helping the nation in its quest for a new selfidentification" (Herzogenrath, 2001, p. 78). In the post-war production of the Adamic archetype, masculinity, suburban space and national mythology converge.

The national obsession with innocence as an aspirational feature of the post-war communities mobilised the proliferation of narratives engaging with the American Adam archetype and its embodiment as the ideal masculine type. The suburbs, in turn, became the perfect setting for the realisation of the archetype, as the post-war cultural construction of the suburbs encouraged a new beginnings narrative where the flight to the suburbs was frequently articulated in terms of a return to paradise (Mitchell, 2011, p. 2; Murphy, 2009, p. 5). This return to paradise entailed a "consequent reification of gender identities" (Beuka, 2004, p. 2) that affected both femininity and masculinity ideals, which now had to respond to a "heightened valorization of the nuclear family" (Beuka, 2004, p. 2). These are the ideological premises that have long accompanied the cultural representation of the suburbs despite their actual heterogeneity, as William Sharpe and Leonard Wallock explain: "the ideology of suburbia—as embodied in film, television and other forms of mass culture - still aggressively perpetuates the stereotypes upon which the traditional suburb was built" (1994, p. 23). A mythic blend of fiction and reality, the idealised image of the 1950s suburban bliss has been re-narrativised time and again in subsequent cultural expressions. 
This paper brings to the fore the ways in which Blue Velvet re-narrativises the myth of the American Adam, now relocated to the US suburbs, in order to delve into the film's use of a masculinity paradigm typical of the 1950s — an archetype closely related to nation-building and the formation of a normative national identity. In particular, the present study explores how R. W. B. Lewis' American Adam myth, despite being out of scholarly fashion, has in fact been utilised time and again in popular culture in ways that can be termed formulaic, as per John Cawelti, whose definition of formula broadly refers to the "ways in which specific cultural themes and stereotypes become embodied in more universal story archetypes" (1977, p. 6). In the case of Blue Velvet, the archetypal story of a heroic quest is re-narrativised in terms of the specific national mythology that the Adamic archetype promotes. Ultimately, this paper means to contribute to the ever-expanding scholarly work on Lynch by arguing that Blue Velvet's conflation of masculinity types, spatiality and dominant national mythology situates his filmic production in a place that, in the case of Blue Velvet, stands closer to dominant culture than to radical eccentricity.

Methodologically, this paper proceeds by analysing character and setting representation in terms of the cultural meanings they convey, paying special attention to Blue Velvet's investment in cultural stereotypes. This approach relies on an idea of film "not as an imitation of reality but rather as an artifact, a construct" (Stam, 2000, p. 186) where cultural meanings are inscribed, and which ultimately represents a "historically contextualized discourse representing psychological concerns and ideology" (Bacon, 2014, p. 405). After introducing the myth of the American Adam, an overview of the ideological implications of popular culture representations of the US suburbs is offered in the attempt to spell out how space and masculinity, in the Adamic archetype, are ideologically co-dependent. This is followed by an analysis of Blue Velvet's interaction with these two elements, focusing on the main character's embodiment of the American Adam myth. As I hope to demonstrate with my analysis, Lynch's use of the (suburban) Adam in Blue Velvet emerges as an example of how popular culture interacts with dominant national narratives in ways that often reinforce gender stereotypes that are functional to national myth-making. This paper concludes by reflecting upon how Lynch's work may be qualified as elusive rather than straightforwardly subversive due to its engagement with and reproduction of hegemonic masculine archetypes.

\section{Blue Velvet's suburban landscape}

David Lynch's 1986 film Blue Velvet deliberately situates us within the cultural imaginary described above through its opening scenes. The very first shots after the credits, 


\section{GENDER STUDIES 20(1)/2021}

appropriately termed "mythic icons" by Jana Evans Braziel (2004, p. 107), carry a deep semiotic meaning and play with the audience's cultural assumptions about the stereotypes related to the suburban environment. Presenting the suburbs as "a state of mind based on imagery and symbolism" (Jackson, 1987, pp. 4-5.) rather than as actual places, we see a spotless white picket fence with red roses on the front, all against an immaculate blue sky, followed by images of old fire trucks and kids orderly crossing the road. This sequence immediately addresses the cultural imaginary of the viewer by suggesting the idea of an orderly, cooperative and decent community ultimately associated to an idealised vision of the US suburbs. The iconicity of these images invites the audience to think in terms of myth rather than reality and prepares the ground for an almost banal reading: the white picket fence evokes suburban innocence while the red roses can be conventionally associated with passion, violence or sex-elements that are central to the movie's plot. The superficial symbolic reading of these images - a banality that Michel Chion considers necessary for the plot (1995, p. 89) — could be deemed superfluous were it not for the fact that not only the movie in particular, but the representation of suburbia in popular culture in general heavily relies on formulaic binary oppositions such as good and bad, or innocence and experience.

Lumberton, the movie's fictional setting, encapsulates the mythic imaginary through its stereotyped embodiment of a suburban neighbourhood. Although, as Richard Martin reminds us, Lumberton is not really a suburb (2013, p. 238), the initial images go out of their way to unmistakably situate the audience in a suburban dreamscape. Reality is displaced in favour of a mythologised recreation of the US suburbs, situating the audience in "imaginary small-town America" (Coughlin, 2003, p. 305, emphasis added), or, as Chion terms it, in "Lynchtown" (1995, p. 83). Lynch's recurrent "cute, typically American, small town" "where one is protected from emptiness and a feeling of cosmic darkness" (Chion, 1995, p. 83), is an almost formulaic landscape that conveys a simultaneous feeling of placelessness and familiarity. Lynch himself declared in an interview that he picked the toponym "Lumberton" precisely because, as there are "many Lumbertons in America," it would convey a feeling of verisimilitude (Chute, 1986, p. 32). From The Simpsons' Springfield to the setting of the 2019 film Greener Grass, the suburbs have been consistently conceived as an interchangeable setting, not tied to a specific geography. As Douglas Muzzio and Thomas Halper put it, "Most suburban movies could have been set elsewhere, usually in a conventional small town, without much difficulty" (2002, p. 547), suggesting that the suburbs-and whatever happens in them-are nowhere and everywhere at the same time. 
The ambiguity surrounding the reality of suburban place is coupled with the difficulty to identify the time when Blue Velvet is set. Lumberton is presented as an ahistorical town which, precisely because of its sense of timelessness, acts as a perfect recipient of stock characters, spaces and narratives, and, more than anything, as the most adequate setting for the materialisation of the American Adam as an individual "emancipated from history" (Lewis, 2001, p. 5). Paradoxically enough, the feeling of timelessness is conveyed through the appearance of very time-specific elements belonging to different decades, all tied together by the overarching presence of Bobby Vinton's 1963 cover of the song "Blue Velvet", featured along the opening images. Norman K. Denzin outlines the mix of different temporalities in the movie:

Within four scenes the film shows cars from the 1950s, 1960s and 1980s moving along Lumberton's streets. Sophisticated 1980's computerized medical equipment is shown in a late 1940's hospital room, and a scene from a 1950's movie flashes across a black and white TV screen. High school students are shown in dress which spans three decades. This is a film which evokes, mocks, yet lends quasi-reverence for the icons of the past, while it places them in the present (1988, p. 469)

While Denzin is right in detecting the mix of elements, I cannot concur with the idea that the film aims to place these icons in the present: Blue Velvet is not bringing some past into the movie's present, but rather producing an ahistorical, suspended time and space which has subsumed icons from different eras associated with the mythologised view of the suburbs. This simultaneous juxtaposition of signifiers, although it does suggest the feeling of "time being out of joint" (Dines, 2012, p. 963), is not necessarily jarring because the movie has already placed its audience at the level of myth. In keeping with the oneiric quality of this and other of his movies, Lynch presents us with the dream of suburbia, producing a space that conforms ideologically to inhabitants like the American Adam. Lisa Fletcher explains how "writers and readers of popular fiction understand that there is a powerful correspondence between types of settings and types of narratives" (2016, p. 1), and the suburbs, in Lynch's rendition, stand in a direct relationship to Lewis' Adamic masculinity type. Through the American Adam's emergence in a setting that was "seen from the outset to have an innate connection with the very character of the nation itself”' (Murphy, 2009, p. 5), national myth, gender ideals and space are blended together in the production of Blue Velvet's seemingly suburban idyll. 


\section{GENDER STUDIES 20(1)/2021}

\section{The hero of the new adventure: A twofold Adam}

The idyll ends soon, however, when we witness a man have a stroke while peacefully watering his garden, establishing a contrast between the joyful feeling of the background song and the dramatic event that is taking place. As Fredric Jameson noted, this event triggers an instant break of the mood that the images have set so far, as it "opens the film like an incomprehensible catastrophe - an act of God which is peculiarly an act of scandalous violence within this peaceful American small town" (1992, p. 294). The next scene introduces us to the man's son, Jeffrey Beaumont (Kyle MacLachlan), who in his return home to take care of his convalescent father, finds a severed ear in a field. Jeffrey, who has been termed a "hero" by critics like Michael Carroll (1993), runs to the police department to report about his uncanny finding, lending himself to any possible cooperation and establishing himself as, indeed, the Adamic "hero of the new adventure" (Lewis, 2001, p.5). The severed ear marks the beginning of Jeffrey-as-Adam's adventure, in which he embodies "a figure of heroic innocence and vast potentialities, poised at the start of a new history" (Lewis 2001, p. 1). Jeffrey certainly fulfils the main features of the American Adam: he is resolute and relies on "his own unique and inherent resources" (Lewis 2001, p. 5) to solve the mystery he is enveloped in. Additionally, Jeffrey adapts to the hegemonic masculinity related to the Adamic archetype: he is a white, heterosexual male, remarkably young and willing to, self-reliantly, cooperate with-and thus improve- his community. Most importantly in terms of the Adamic archetype, Jeffrey is innocent. Once confronted with the mystery of the severed ear, he adopts the role of an amateur detective worried about the wrongdoings of his community, whose underlying evil and corruption will repel just as much as it will fascinate him. By this point, the setting for the plot driven by the American Adam has been established: the suburban environment of Lumberton becomes the backdrop to the mystery that suggests there is something rotten beneath the idyllic town surface, providing Jeffrey, the Adamic hero of Lynch's story, with a rationale to probe into the realm of the corrupted.

Jeffrey soon falls for the charms of Sandy (Laura Dern), Lumberton's detective's daughter, who readily emerges as a stereotyped embodiment of pure innocence and candour, presented in a deliberately exaggerated way that, as Frida Beckman notes, paves the way for an ironic reading of her character (2012, p. 37). After exchanging their views on the mysterious severed ear, Sandy tells Jeffrey about the enigmatic nightclub singer Dorothy Vallens (Isabella Rossellini) and the secrecies that surround her, leading Jeffrey to pursue a dangerous quest. Ironically, it is innocent Sandy and not Dorothy, the movie's femme fatale, who entices Jeffrey 


\section{GENDER STUDIES 20(1)/2021}

into exploring Dorothy's criminal underworld. Jeffrey and Sandy decide to pursue this investigation almost as an entertainment, aware that their status as respectable suburbanites will protect them of neighbourly suspicion:

SANDY: I don't know. It sounds like a good daydream, but actually doing it is too weird. Too dangerous. JEFFREY: Let's just try the first part. If that goes well, we'll see about the rest. No one will suspect us, because no one would believe two people like us would be crazy enough to do something like this.

SANDY: You've got a point there. (Lynch, 1986, emphasis added)

There is a vast deal of meaning in Jeffrey's mention of "two people like us." Tacitly, both he and Sandy identify themselves as virtuous citizens, unlikely to get into trouble and, most importantly, unlikely to be thought of as troublemakers by the rest of the community. Not by chance, as soon as Detective Williams finds out that Jeffrey has become aware of the unlawful dealings that surround Dorothy, the first thing he asks, repeatedly, is "Is Sandy a part of this?" (Lynch, 1986), as though the wholesome, decent Sandy could not possibly have crossed the line between innocence and perversion.

Blue Velvet's delimitation of identities is accompanied by a subsequent delimitation of spaces. In order to pursue his investigation, Jeffrey has to abandon the secure environment of the suburbs and penetrate into the sombre atmosphere of urban Lumberton, where Dorothy Vallens lives. Jeffrey and Sandy's identities are defined by the space they inhabit: they embody the wholesomeness and innocence of the idealised suburb, standing in stark contrast to the urban, shadowy world that Dorothy Vallens inhabits. In a movie that hinges on fossilised gender stereotypes, Jeffrey's innocent masculinity-highlighted by Sandy's exaggerated candour-opposes Dorothy's guilty femininity, in tune with her role as femme fatale. When Jeffrey, fascinated by Sandy's account of Dorothy's life, asks her if she knows where she lives, Sandy replies: "Yeah. It's close by. That's what's creepy" (Lynch, 1986). Sandy's answer is formulaic in that it reproduces a common trait of mainstream suburban ideology, namely, that whatever is deemed as Other-dangerous, perverted, different—is shut out from the suburban safe environment, but always lurking close as a threat, as Jonathan Mitchell has explained: "this sense of paradise regained, which reached its most dominant expression in the 1950s suburban living, went hand in hand with insecurity and paranoia" (2011, p. 2). Once again, Jeffrey and Sandy become the repositories of the commonplace ideas associated to suburban living in popular culture, according to which the private comfort of the suburban home is conceived as a shelter that protects its dwellers from the manifold dangers of the adjoining urban areas. 


\section{GENDER STUDIES 20(1)/2021}

In particular, the fact that Dorothy lives in an apartment building named Deep River located in the urban area of Lumberton further contributes to the delimitation of her identity as incompatible with the suburban ideology that Sandy and Jeffrey represent. Incidentally, the discourse surrounding the differences between choosing to live in a suburban house and an apartment had been a matter of a national debate during the twentieth century, with President Herbert Hoover privileging the suburbs as a more American aspiration as compared to other housing options:

\footnotetext{
I am confident that the sentiment for home ownership is so embedded in the American heart that millions of people who dwell in tenements, apartments, and rented rows of solid brick have the aspiration for wider opportunity in ownership of their own homes. To possess one's own home is the hope and ambition of almost every individual in our country, whether he lives in hotel, apartment or tenement (Hoover, n.p.)
}

Inhabiting the suburbs or an apartment in a "rented row of solid brick" thus became a moral choice, a divider between acceptable and questionable aspirations. Against the wellmowed, welcoming front yards of the suburbs, Dorothy Vallens' apartment is governed by notions of insecurity, perversion and wickedness, but also of irrepressible attraction, as Justus Nieland states: “these spatial 'outsides' to small-town domesticity declare their status as desired and feared" (2012, p. 37). When Jeffrey goes up to Dorothy's apartment dressed as a bug-killer, she opens the door only partially, afraid of what might be waiting on the other side. Once we get to see her apartment we realise its quirkiness and the great divide that exists between the Edenic realm of the suburbs and the corrupted world of the urban. Peeking into her home, we learn that the prototypically Bachelardian idea of home as a safe haven that the suburbs represent is denied to Dorothy.

The spatial demarcation of identities is one defining feature of the American Adam, who always emerges in relation to space: he is either in Eden or expelled from Eden. Blue Velvet perpetuates this idea considering that it is through the dialectic of spaces that the duplicitous character of the American Adam comes to light in Lynch's movie. Jeffrey, although he embodies the innocence inherent to the Adamic archetype, transgresses the limits of his wholesome world when he sneaks into Dorothy's home and, hiding, becomes a voyeur behind her closet's doors. Once that Jeffrey has crossed this threshold, he becomes a liminal figure who gives in to the American Adam's archetypal identity conflict, in which "the favorite characters are boys awaiting initiation into maturity" (Patea, 2001, p. 23). This creates a duplicity in Jeffery that Sandy realises soon when, after being shocked by his resolution to go up to Dorothy's apartment, she tells him: "I don't know if you're a detective or a pervert," to 


\section{GENDER STUDIES 20(1)/2021}

which he replies: "That's for me to know and for you to find out" (Lynch, 1986). The quest becomes a test for Jeffrey, one that will determine on which side he is standing, and that in turn points to his twofaced identity.

Several critics have interpreted Blue Velvet as a masculine coming-of-age story, revolving around the sexual awakening of the main character and his transition from innocence to experience (Berry, 1988; Denzin, 1988; Nieland, 2012). Jeffrey himself states that "There are opportunities in life for gaining knowledge and experience" (Lynch, 1986), as though he was aware of what is at stake in his involvement with Dorothy's world. Jeffrey's personal journey moves between his teenage, innocent love for Sandy and the decidedly sexual, erotic attraction he feels for Dorothy. Again, Jeffrey's romantic aspirations with Sandy are circumscribed to the suburban space, where, stereotypically, discreet teenage love emerges - not by chance did Lewis Mumford deem that the suburbs were "based on a childish version of the world (1961, p. 494)—whereas his incursions in Dorothy's apartment relate to an adult sexual awakening. This awakening, though, is anticlimactic if we consider that Jeffrey's first encounter with Dorothy is remarkably emasculating, rendering him a child in her eyes.

Once Dorothy realises Jeffrey is hiding in her closet, Jeffrey tries to justify his presence and eloquently confesses: "I sprayed your apartment. I took your key. I really didn't mean to do anything but see you" (Lynch, 1986, emphasis added). Clumsily acknowledging his voyeuristic intentions and locating Dorothy as a sexual object, Jeffrey invokes the "masculine privileging paradigm" of the American Adam: "to evoke the American Adam is to designate women as Eve: secondary to man and subjected to his rule" (Mitchell, 2011, p. 5). However, after understanding that Jeffrey has been secretly gazing at her undressing in a way that sexually objectifies her, Dorothy takes the lead and exhorts Jeffrey: "Get undressed!" (Lynch, 1986). This is the move that critics like Coughlin (2003, p. 309) have frequently read as emasculating for Jeffrey, given that he loses control of a situation where the positions of subject and object are inverted. From now on, Jeffrey navigates between the archetypal innocence he embodies-a status which, according to Patea, is the "consequence of an emasculating anxiety" (2001, p. 36) - and the conflicted identity associated to a problematic sexual awakening — something which, again, makes him an almost textbook embodiment of the American Adam.

Jeffrey's liminal position is emphasised when Frank Booth (Dennis Hopper) enters the scene storming into Dorothy's apartment "like the father of a long-running television sitcom returning home from a hard day at the office" (Coughlin, 2003, p. 306). Enacting an instant 
reversal to the classic (dysfunctional) heterosexual couple type that featured in popular culture representations of the fifties and yelling "Where is my Bourbon?" (Lynch, 1986), Frank appears as Jeffrey's foil: he is violent and abusive, as well as completely oblivious of Dorothy's wellbeing, calling her "shithead" and forcing her to call him "daddy" (Lynch, 1986). We soon learn that Frank, the leader of a drug gang, has kidnapped Dorothy's husband and child, and routinely submits Dorothy to verbal and physical violence. Once again, we see Dorothy being subjected to the violence of masculine rule. Significantly, Frank is obsessed about not letting others look at him, as though he was the only one allowed to have a gaze. His actions are complementary to those of Jeffrey's, who in his role as a voyeur, is also in command of who looks and who is looked at. The dysfunctional idea of masculinity embodied in the duplicitous nature of the American Adam is further represented by Frank's need of his inhaler every time he intends to accomplish an action associated to his conception of masculinity, that is, sex or violence (or violent sex).

The pairing of Jeffrey/Frank as the (blurry) representation of innocence/evil runs through virtually most of Lynch's work, where many of his male characters reiterate the binary - think, for instance, of Twin Peaks' agent Cooper and B.O.B., and how their identities become intertwined in the season two finale. The apparently oppositional identities of Jeffrey and Frank are in reality the two sides of the American Adam, with Jeffrey standing for (pseudo)innocence and Frank for pure evil, summarising the states that the archetype can manifest, as Mitchell explains: "To commit to the American Adam is to evoke both the existence of an a priori state of innocence and subsequent fall or possible fall" (2011, p. 13). Blue Velvet, through the Jeffrey/Frank pairing, encapsulates both the pre- and the post-lapsarian states of the American Adam and ultimately emphasises how the antagonism between Jeffrey and Frank is only apparent, as Jeffrey traverses the line between innocence and perversion on several occasions. Frank seems to be aware that is the case when he blurts out to Jeffrey: "You're like me" (Lynch, 1986), as if he was warning him against his feelings of moral superiority. Jeffrey, who we know sees himself as an innocent hero, wonders: "Why are there people like Frank?," whom he later describes as "A very sick and dangerous man" (Lynch, 1986). Jeffrey, whose rhetoric here resembles that of a child, is trapped in his morally superior image of himself, despite his incursions in violent behaviour against Dorothy. In this, he displays the "boyishness in American behavior" (Boose, 1993, p. 609) that characterises the 


\section{GENDER STUDIES 20(1)/2021}

American Adam as a "righteously innocent adolescent" (Boose, 1993, p. 609). ${ }^{5}$ Besides hitting her and feeling deeply guilty about it afterwards, Jeffrey basically lets Frank rape Dorothy—as much as he is struggling to witness the ghastly scene, he does not act as a heroic Adam but with complicity through his inaction, casting Dorothy, once again, as "secondary to man and subjected to his rule", Mitchell, 2011, p. 5). Because "The Adamic paradigm contains the ideal and the desecration of the ideal, Adam's rise and fall, his apotheosis as well as his ruin" (Patea, 2001, p. 27), Blue Velvet's engagement with the American Adam archetype ultimately suggests that there can be no Jeffrey without Frank.

\section{Order restored?}

The contradictions embodied in the Adamic type are apparently resolved in Blue Velvet, when Jeffrey ends Dorothy's suffering by murdering Frank. Put simply, the American Adam of Lynch's movie reinstalls innocence and eliminates corruption: Jeffrey finally reunites with Sandy, who is able to forgive his incursions into Lumberton's underworld, and Dorothy is absolved from her part as a femme fatale. We observe her playing happily with her child, dropping her role as a sexual object and embodying the maternal character that is expected from her in the community of Lumberton. ${ }^{6}$ The two-sidedness of the American Adam vanishes, and innocence wins over evil, as happens in archetypal Adamic narratives that end up fostering "a (re)commitment to a basic mythic identity of being American" (Mitchell, 2011, p. 5). Jeffrey, through his commitment to justice, fulfils the basic aspirational principles of the self-reliant, adventurous male who risks his own integrity for the sake of the community's well-being. By the end of the movie, Jeffrey-as-Adam has been "plunged again and again, for his own good and for ours, into the spurious, disruptive rituals of the actual world" (Lewis 2001, p. 198) and has come back triumphant. With Frank's death at the hands of Jeffrey, evil has been apparently eliminated and the suburban status quo reinforced, with Jeffrey's dad health recovered and Sandy calling Jeffrey as lunch is ready in the neat, suburban house. As Coughlin argues, "Blue Velvet's coda [...] details a world restored to balance" (2003, p. 309). Borrowing from John

\footnotetext{
5 In a chapter titled "Techno-Muscularity and the 'Boy Eternal:' From the Quagmire to the Gulf" where she discusses the construction of masculinity in post-Vietnam culture, Lynda Boose argues that the pervasiveness of adolescent, boyish characters in US cultural manifestations actually speaks of “America's 'crew-cut' version of itself," based on "a mythic self-image that allows the nation to behave in just such massively irresponsible ways as its foreign policies reflect" (Boose, 1993, p. 609-610).

${ }^{6}$ Dorothy's "happy ending" is also indebted to Jeffrey-as-Adam's heroic action, making her remain subject to masculine action, whether good or bad.
} 


\section{GENDER STUDIES 20(1)/2021}

Cawelti's classic argument, Blue Velvet thus commits to what can be termed the Adamic formula, understood as

an archetypal story pattern embodied in the images, symbols, themes, and myths of a particular culture. As shaped by the imperatives of the experience of escape, these formulaic worlds are constructions that can be described as moral fantasies constituting an imaginary world in which the audience can encounter a maximum of excitement without being confronted with an overpowering sense of the insecurity and danger that accompany such forms of excitement in reality. (1977, p.16)

Blue Velvet, for all its destabilising qualities, underwrites a national narrative replete with fossilised cultural meanings that are an integral part of the movie's plot. Fredric Jameson noted this when he wrote that "[h]istory therefore enters Blue Velvet in the form of ideology, if not of myth: the Garden and the Fall, American exceptionalism, a small town" (1992, p. 2945), emphasising how hegemonic thought pervades popular culture, even in products that are typically defined as subversive, transgressive or ground-breaking as are Lynch's films.

Lynch's commitment to the formula is not absolute, though. Rather than merely reproducing the Adamic moral fantasy, to borrow Cawelti's term (1977), Lynch is playing with a pervasive national myth in a way that both enhances and destabilises the fantasy. Lynch disrupts the formula by incorporating a feeling of eeriness that runs through the movie's final scenes. Although the restored order of Blue Velvet's ending confirms the recommitment to the mythic identity of the American Adam, the audience is left with the feeling that order restored is temporary and partial rather than definitive. The closing images of the movie go back to the blue skies and white picket fences, but these images are not the same ones from the beginning; not only because the flowers are not the same, but also because we know that the suburban dream of the initial sequence has now been revealed to be tainted with the complex and problematic identity of the American Adam. The robin that appears in the final scene standing on the kitchen windowsill could pass as a quasi-pastoral signifier of the return to innocence. But the bird's uncanny, mechanical movements while it devours a beetle suggest that there is no innocence without destruction. This shot establishes a circular connection with a similar scene at the beginning of the movie, when, after Jeffrey's dad has collapsed, the camera zooms in to a net of buzzing black insects, somehow suggesting that underneath the surface of the perfectly mowed suburban yard lies a world of disgust. 


\section{GENDER STUDIES 20(1)/2021}

\section{Conclusions}

As I have shown in the previous analysis, Jeffrey's embodiment of the Adamic archetype indicates that Blue Velvet incorporates aspects of dominant masculinity that have long acted as the bedrock of US national identity. Through the mobilisation of a masculinity type based on innocence and self-reliance, traditionally embodied by a white, male, heterosexual hero, Lynch's film reproduces Lewis' mid-century masculinity ideal in a virtually unaltered manner. This paper has attempted to show how the analysis of Blue Velvet's ideological implications, especially regarding its depiction of masculinity, demonstrates that the film utilises — and, to a significant extent, reproduces — the myth of the American Adam as the ideological template for its protagonist, who, throughout the course of the movie, reveals himself to embody the qualities of this archetype, both in a pre-lapsarian and a post-lapsarian state, represented by the Jeffrey/Frank pairing. By taking place in a setting that has consistently be taken to be emblematic of national identity, the movie allows for a reading that considers the interaction of gender, space and national narratives.

Blue Velvet ultimately provides a vantage point from which to assess the impact of 1950s cultural archetypes like Lewis' American Adam, which, as explained in the introduction, promoted an idea of masculinity deeply imbricated in the fabrication of national ideology. What Lewis termed "the indestructible vitality of the Adamic vision of life" (2001, p. 198), the bedrock of his attempt to outline a "native American mythology" (2001, p. 1), lives on in cultural products like Blue Velvet. But it lives on along with the acknowledgment that a mythic design like the American Adam is problematic and unattainable, as Brad Dourif, who plays Frank Booth's buddy Raymond, states: "Blue Velvet is a story about innocence and the impossibility of it” (qtd. in Lynch \& McKenna, 2019, p. 213). This impossibility was already detected by Lewis when he plainly argued that the American Adam "has been frowned quite out of existence" (2001, p. 195): the morally immaculate, eternally innocent man was finally accepted to be a hopeless ideal in the post-war culture. Viorica Patea provides an historical explanation for this:

The notion of a self-sufficient and innocent Adam was wholly incompatible with a postwar worldview that saw the self's power as limited and the world as a less malleable setting for the self's realization of its projects. The experience of violence and the absurd left its imprint on the American self and on ideas about Adamic innocence. (2001, p. 37) 
Somehow mirroring Jeffrey's symbolic emasculation in the movie, the demoralising post-war years presented a challenge to a masculinity model that was based on the unfulfilled potential of male action. In the realisation of such impossibility, R. W. B. Lewis and David Lynch may coincide. But while Lewis falls into a jeremiad about the aspirations of the United States, lamenting "the chilling skepticism of the mid-twentieth century" (Lewis, 2001, p. 196), Lynch reimagines the fixations of an era that is long gone. In this reimagining, Blue Velvet reinstates the centrality of the heterosexual male as hero promoted by the American Adam, especially as the protagonist of the suburban dream of the 1950s against the backdrop of postwar culture.

In this sense, Lynch's engagement with the myth of the American Adam is not so much, as several scholars have read, an indictment of the evils of suburban life and characters that replicates the stock criticism of anti-suburban literature of the fifties and sixties, but an intricate homage to an era that he has repeatedly claimed to be fascinated with (Lynch \& McKenna, 2019, p. 12). Against widespread readings that have prioritised either the moralising (Johnson, 2003) or the subversive and parodic elements in Lynch's films (Coughlin, 2003; Berry, 1988), less suspicious interpretations of his work like Carroll's, which locates Lynch's work within "the most fundamental myth of American culture" (1993, p. 294), can shed light on the interaction that exists between popular culture, gender construction, and national mythologies. David Lynch's own tendency to dwell in the cracks of what are considered primal dualities of life, such as good and evil or beauty and horror-dualities that also inform the myth of the American Adam — is also understood, by Lynch himself, in terms of a national narrative: “This is all the way America is to me. There's a very innocent, naïve quality to my life, and there's a horror and a sickness as well. It's everything" (qtd in Chute, 1986, p. 32). Totalising statements that assess Lynch's work in reductionist terms run the risk of overlooking the deliberate elusiveness of his films, as well as their supposedly unlikely engagement with hegemonic national narratives. This paper has attempted to contribute to the field of Lynchian studies by examining how the channelling of dominant national identity through ideal masculinity types is refashioned in cultural products, even in those which are typically considered to be subversive. Spatial, gender, and ultimately, national archetypes in Blue Velvet are then not a thing to be debunked but explored as a symptom of the intricacies and endurance of dominant cultural myths. 


\section{GENDER STUDIES 20(1)/2021}

\section{Acknowledgments}

The research carried out for this paper has been funded by the Spanish Ministry of Universities (FPU-2019).

\section{References}

Bacon, H. (2014). Representation. In E. Branigan \& W. Buckland (Eds.), The Routledge encyclopedia of film theory (pp. 402-407). Routledge.

Ball, T. (2002). Reappraising political theory. Revisionist studies in the history of political thought. Oxford University Press.

Baym, N. (1981). Melodramas of beset manhood: How theories of American fiction exclude women authors. American Quarterly, 33(2), 123-139.

Beckman, F. (2012). From irony to narrative crisis: Reconsidering the femme fatale in the films of David Lynch. Cinema Journal, 52(1), 25-44.

Beuka, R. (2004). SuburbiaNation: Reading suburban landscape in twentieth-century American fiction and film. Palgrave Macmillan.

Berry, B. (1988). Forever, in my dreams: Generic conventions and the subversive imagination in Blue Velvet. Literature/Film Quarterly, 16(2), 82-90.

Boose, L. (1993). Techno-muscularity and the "boy eternal:" from the Quagmire to the Gulf. In A. Kaplan \& D. E. Pease (Eds.), Cultures of United States imperialism (pp. 581-616). Duke University Press.

Braziel, J. E. (2004). 'In dreams...': Gender, sexuality and violence in the cinema of David Lynch. In E. Sheen \& A. Davison (Eds.), The Cinema of David Lynch: American Dreams, Nightmare Visions (pp. 107-118). Wallflower Press.

Carroll, M. (1993). Agent Cooper's errand in the wilderness: Twin Peaks and American mythology.

Literature/Film Quarterly, 21(4), 287-295.

Cawelti, J. G. (1977). Adventure, Mystery, and Romance: Formula Stories as Art and Popular Culture. U of Chicago P.

Chion, M. (1995). David Lynch. R. Julian (Trans.). BFI Publishing.

Chute, D. (1986). Out to Lynch. Film Comment, 22(5), 32-35.

Coughlin, P. (2003). Postmodern parody and the subversion of conservative frameworks. Literature/Film Quarterly, 31(4), 304-311.

Denzin, N. K. (1988). Blue Velvet: Postmodern contradictions. Theory, Culture \& Society, 5, 461-473.

Dines, M. (2012). Suburban gothic and the ethnic uncanny in Jeffrey Eugenides's The Virgin Suicides. Journal of American Studies, 46(04), 959-975.

Fletcher, L. (2016). Introduction: Space, place, and popular fiction. In L. Fletcher (Ed.), Popular fiction and spatiality: Reading genre settings (p. 1-8). Palgrave Macmillan US.

Herzogenrath, B. (2001). The American Adam revisited: American literature, (national) identity, and the logic of belatedness. In V. Patea \& M. E. Díaz Sánchez (Eds.), Critical essays on the myth of the American Adam (pp. 65-80). Ediciones Universidad de Salamanca. 


\section{GENDER STUDIES 20(1)/2021}

Hoover, H. (1931). Address to the White House conference on home building and home ownership. The American Presidency Project. (n.d.). Retrieved from https://www.presidency.ucsb.edu/ documents/address-thewhite-house-conference-home-building-and-home-ownership

Jackson, K. T. (1987). Crabgrass frontier: The suburbanization of the United States. Oxford University Press.

Jameson, F. (1992). Postmodernism, or, the cultural logic of late capitalism. Verso.

Johnson, J. (2003). Pervert in the pulpit: The puritanical impulse in the films of David Lynch. Journal of Film and Video, 55(4), 3-14.

Lewis, R. W. B. (2001). The American Adam: Innocence, tragedy and tradition in the 19th century. U of Chicago P.

Lynch, D. (Director). (1986). Blue velvet [Film]. De Laurentiis Entertainment Group.

Lynch, D., \& McKenna, K. (2019). Room to dream. Canongate Books.

Martin, R. (2013). Neighbourhoods or nothing? Social relations in David Lynch's Blue Velvet. European Journal of American Culture, 32(3), 235-247.

Mitchell, J. (2011). Revisions of the American Adam: Innocence, identity and masculinity in twentieth century America. Continuum.

Méndez García, C. M. (2014). Gótico y espacios suburbanos en la literatura posmoderna. Herejía y Belleza, 2 , $115-130$.

Mumford, L. (1961). The city in history. Harcourt Brace Jovanovich.

Murphy, B. (2009). The Suburban Gothic in American Popular Culture. Palgrave Macmillan.

Muzzio, D., \& Halper, T. (2002). Pleasantville?: The suburb and its representation in American movies. Urban Affairs Review, 37(4), 543-574.

Nieland, J. (2012). David Lynch. University of Illinois Press.

Patea, V. (2001). The Myth of the American Adam: A Reassessment. In V. Patea \& M. E. Díaz Sánchez (Eds.), Critical essays on the myth of the American Adam (pp. 15-45). Ediciones Universidad de Salamanca.

Sharpe, W., \& Wallock, L. (1994). Bold new city or built-up 'burb? Redefining contemporary suburbia. 46(1), 130 .

Slotkin, R. (1996). Regeneration through violence: the mythology of the American frontier, 1600-1860. HarperPerennial.

Stam, R. (2000). Film theory: an introduction. Blackwell Publishers.

Sofía MARTINICORENA is a doctoral fellow at the English Studies Department of the Complutense University of Madrid. After obtaining a master's degree in United States Literature at the University of Edinburgh (2017-2018), she is currently writing a doctoral thesis on heterotopias and contemporary US literature, where she focuses on narratives of the west and the suburbs, and the cultural imaginaries related to these geomythic spaces. Her research interests include, but are not limited to, US literature, space studies, critical geography, popular US culture, myth criticism and gender studies. She has participated in conferences and seminaries relating to the field and has published articles on varied topics, including United States space and place, Joan Didion or film studies. 